Buana Sains Vol 17 No 2: 137 - 142, 2017

\title{
KERAGAMAN FENOTIPE DAN PRODUKTIVITAS LABU KUNING NUSANTARA (Cucurbita moschene Dutchene) DALAM RANGKA PENGEMBANGAN VARIETAS UNGGUL
}

\author{
Reza Prakoso Dwi Julianto dan Astri Sumiati \\ Program Studi Agroteknologi, Fakultas Pertanian, Universitas Tribhuwana Tunggadewi
}

\begin{abstract}
Indonesia is one of the rich countries with germplasm resources, compared with other countries. The biodiversity is used as a source germplasm that plays a role in all aspects of agriculture especially for activities plant breeding in order to develop new hybrid varieties. Pumpkin plants on East Java is one of the commodities that have long been cultivated by community and used as a foodstuff, but until now the hybrid varieties are available in the community is very limited, so the need for an attempt to assembly new varieties of plant breeding activities. Plant breeding activities begin from genetic pooling or potential germplasm collection, assembly, processes release and utilization to the user farmers. This study was conducted with the aim to collect the seeds of local varieties and then identify the phenotype and agronomy. Exploration activities were conducted in three areas, Malang, Lumajang, and Magetan. Field identification activities were carried out in two locations, Malang and Lumajang. The results of this study indicate that local varieties have pest resistance and a relatively resistant disease, The number of female flowers of all varieties of local pumpkin planted has fewer amounts than the number of male flowers, Size leaves on varieties of local pumpkins from all locations have varying sizes, Age of male and female flowers in all varieties of local pumpkin from both locations has a flowering age that is relatively same, fruit peel of local pumpkin has brown color, Fruit color on local pumpkin Malang has orange color.
\end{abstract}

Keywords : Phenotype diversity, pumpkin, productivity, hybrid, varieties

\section{Pendahuluan}

Indonesia merupakan salah satu negara yang sangat kaya dengan sumber plasma nutfah, dibandingkan dengan negaranegara lain. Keragaman hayati tersebut digunakan sebagai sumber plasma nutfah yang berperan pada semua aspek di bidang pertanian terutama untuk kegiatan pemuliaan tanaman dalam rangka pengembangan varietas unggul baru. Tanaman labu kuning merupakan salah satu jenis tanaman yang dapat digunakan sebagai alternatif bahan pangan sumber karbohidrat. Kandungan nutrisi utama labu kuning adalah karbohidarat, selain itu labu kuning juga banyak mengandung vitamin dan protein serta rendah lemak.

Provinsi Jawa Timur merupakan salah satu provinsi yang masyarakatnya telah lama mengenal dan membudidayakan tanaman labu kuning serta menjadikannya sebagai bahan makanan, meskipun sebagian besar masyarakat masih mengkonsumsi beras sebagai makanan pokoknya. Kebutuhan beras setiap tahun terus meningkat, tetapi produksi beras di Indonesia masih tergolong rendah sehingga belum mampu memenuhi kebutuhan seluruh 
masyarakat. Variasi yang ada sampai sekarang masih belum banyak informasi yang diperoleh terutama tentang sifat unggul yang ada pada varietas labu kuning lokal, padahal didalam perakitan sebuah varietas unggul yang mempunyai tingkat produktivitas, ketahanan terhadap hama dan penyakit yang baik serta sifat unggul lainnya, hal semacam ini sangat dibutuhkan.

Kualitas dan Kuantitas varietas merupakan variabel terpenting dalam proses produksi pertanian, sehingga program perakitan varietas sangat penting dilakukan secara konsisten. Rangkaian kegiatan perakitan varietas dalam satu siklus meliputi genetic pooling atau pengumpulan plasma nutfah potensial, proses perakitan dan proses pelepasan serta pemanfaatannya kepada petani pengguna.

Oleh karena itu, kegiatan penelitian tentang identifikasi keragaman fenotipe dan produktivitas tanaman labu kuning lokal perlu dilakukan dan tidak boleh terlewatkan dalam kegiatan perakitan varietas unggul mengingat dalam setiap perakitan satu varietas unggul baru akan diperlukan waktu paling tidak 3-4 tahun.

Tujuan dari Penelitian ini adalah : Mengumpulkan berbagai jenis varietas labu kuning lokal di Jawa Timur sebagai sumber plasma nutfah; Mengidentifikasi dan mengklarifikasi karakter fenotipe dan agronomis varietas labu kuning lokal

\section{Bahan dan Metode}

Kegiatan eksplorasi dilakukan di tiag wiayah yaitu kabupaten Lumajang, kabupaten Malang, dan Kabupaten Magetan, pada setiap kabupaten dipilih satu kecamatan sentra produksi labu kuning dengan pengambilan sampel sekitar 1-2 sampel. Kegiatan identifikasi lapang dilakukan untuk mengetahui karakter fenotipe dan agronomi, kegiatan ini dilakukan di dua lokasi yaitu di kabupaten Lumajang dan Kabupaten Malang. Bahan yang digunakan dalam penelitian ini berupa benih labu lokal lumajang,labu lokal malang, dan labu lokal Magetan

Parameter pengamatan meliputi pengamatan karakter fenotipe tanaman dan karakter agronomi. Karakter fenotipe antara lain Luas Daun, Ukuran Daun, Bulu Daun, Bulu Tangkai, Umur berbunga, Ratio Bunga jantan dan betina, ketahanan hama penyakit tanaman. Karakter agronomi terdiri dari umur panen, diameter buah, tebal daging buah, lebar rongga buah, warna daging buah, wana kulit buah, rambut pada tangkai buah, dan bobot buah per tanaman.

Penelitian dilaksanakn tanpa menggunakan rancangan. Benih dari masing-masing jenis di tanam kedalam lima (5) baris setiap baris terdiri atas 20 tanaman, dengan menggunakan jarak tanam yaitu $40 \times 100 \mathrm{~cm}$. Hasil penelitian dan pengujian dibuat deskripsi dan interpretasi serta dilaporkan sebagai hasil akhir.

\section{Hasil dan Pembahasan}

Kegiatan identifikasi karakter fenotipe dan karakter agronomis dilakukan di dua lokasi antara lain di Kabupaten Malang dan Kabupaten Lumajang. Benih yang digunakan dalam penanaman ini berasal dari benih labu hasil eksplorasi di tiga lokasi antara lain di kabupaten Lumajang, Malang, dan Magetan. Labu kuning yang dipilih adalah labu yang sudah lama di budidayakan oleh masyarakat sekitar daerah tersebut.

Hasil identifikasi karakter fenotipe dan agronomi dilakukan di Kabupaten Malang diperoleh informasi antara lain tentang luas daun, ukuran daun, bulu daun, bulu tangkai, umur berbunga, ratio bunga betina dan jantan, dan ketahanan hama penyakit. Karakter luas daun varietas lokal Lumajang mempunyai rata- 
rata luas daun sekitar $530 \mathrm{~cm}^{2}$, varietas lokal Malang mempunyai rata-rata luas daun sekitar $583,3 \mathrm{~cm}^{2}$, dan varietas lokal Magetan mempunyai rata-rata $545,5 \mathrm{~cm}^{2}$. Karakter ukuran daun dari semua varietas labu kuning lokal yang ditanam semua nya mempunyai ukuran daun yang bervariasi. Karakter bulu daun dan bulu tangkai dari semua labu kuning yang ditanam mempunyai sifat yang sama yaitu sama-sama mempunyai bulu pada daun dan tangkainya (tabel 1).

Semua varietas lokal yang ditanam mempunyai warna daun hijau ke abuabuan, tetapi berdasarkan identifikasi dilapang diketahui sebagian menunjukkan ada beberapa daun yang berwarna kuning, hal ini mengindikasika jumlah klorofil yang terbentuk semakin sedikit. Faktor utama pembentuk klorofil adalah nitrogen $(\mathrm{N})$. Unsur $\mathrm{N}$ merupakan unsur hara makro. Unsur ini diperlukan oleh tanaman dalam jumlah banyak. Unsur $\mathrm{N}$ diperlukan oleh tanaman, salah satunya sebagai penyusun klorofil. Tanaman yang kekurangan unsur $\mathrm{N}$ akan menunjukkan gejala antara lain klorosis pada daun. Tanaman tidak dapat menggunakan N2 secara langsung. Gas N2 tersebut harus difiksasi oleh bakteri menjadi amonia (NH3) (Anonimous, 2003).

Karakter umur berbunga dari ketiga varietas labu kuning yang di tanam mempunyai kriteria umur bunga jantan lebih cepat dibandingkan dengan umur bunga betina. Umur berbunga jantan dan betina pada varietas labu kuning lokal lumajang yaitu umur 42 hst (hari setelah tanam) dan 44 hst. Varietas labu kuning lokal Malang mempunyai umur berbunga jantan dan betina yaitu 41 hst dan 45 hst. Labu kuning lokal magetan mempunyai umur berbunga jantan dan betina yaitu 41 hst dan 45 hst. Varietas labu kuning lokal malang dan magetan mempunyai umur berbunga jantan dan betina lebih cepat dibandingkan dengan varietas labu kuning lokal Lumajang, sedangkan umur bunga betina labu kuning lokal Lumajang lebih cepat dibandingkan dengan varietas labu kuning lokal Malang dan Magetan (tabel 1).

Tabel 1. Identifikasi Karakter Fenotipe Lokasi Penanaman Kab. Malang

\begin{tabular}{|c|c|c|c|}
\hline Karakteristik & $\begin{array}{c}\text { Labu Kuning Lokal } \\
\text { Lumajang }\end{array}$ & $\begin{array}{c}\text { Labu Kuning Lokal } \\
\text { Malang }\end{array}$ & $\begin{array}{c}\text { Labu Kuning Lokal } \\
\text { Magetan }\end{array}$ \\
\hline \multicolumn{4}{|c|}{ Tanggal Tanam 29 April 2017} \\
\hline Luas Daun & $530 \mathrm{~cm}^{2}$ & $583,3 \mathrm{~cm} 2$ & $545,5 \mathrm{~cm}^{2}$ \\
\hline Ukuran Daun & Bervariasi & Bervariasi & Bervariasi \\
\hline Bulu Daun & Ada & Ada & Ada \\
\hline Bulu Tangkai & Ada & Ada & Ada \\
\hline $\begin{array}{l}\text { Umur Berbunga } \\
\text { Jantan }\end{array}$ & 42 hst & 41 hst & 41 hst \\
\hline $\begin{array}{l}\text { Umur Berbunga } \\
\text { Betina }\end{array}$ & 44 hst & 45 hst & 45 hst \\
\hline $\begin{array}{l}\text { Ratio Bunga } \\
\text { Betina dan Jantan }\end{array}$ & $1: 18$ & $1: 21$ & $1: 21$ \\
\hline $\begin{array}{l}\text { Ketahanan Hama } \\
\text { Penyakit }\end{array}$ & Tahan & Tahan & Tahan \\
\hline
\end{tabular}

Ratio bunga jantan dan betina untuk semua varietas labu kuning lokal yang di tanam mempunyai jumlah bunga jantan lebih banyak dibandingkan dengan jumlah bunga betina, varitas labu kuning lokal Lumajang mempunyai perbandingan bunga jantan dan betina yaitu 1:18, varietas labu kuning lokal 
R.P.D. Julianto dan A. Sumiati/Buana Sains Vol 17 No 2 : 137 - 142

Malang perbandingannya yaitu 1:21, dan varietas labu kuning lokal Magetan mempunyai perbandingan 1:21 untuk jumlah bunga jantan dan bunga betina.
Karakter ketahanan hama dan penyakit untuk semua varietas lokal yang di tanam di lokasi kabupaten Malang mempunyai kriteria tahan (Tabel 1).

Tabel 2. Identifikasi Karakter Fenotipe Lokasi Penanaman Kab. Lumajang

\begin{tabular}{|l|c|c|c|}
\hline Karakteristik & $\begin{array}{c}\text { Labu Kuning } \\
\text { Lokal Lumajang }\end{array}$ & $\begin{array}{c}\text { Labu Kuning } \\
\text { Lokal Malang }\end{array}$ & $\begin{array}{c}\text { Labu Kuning } \\
\text { Lokal Magetan }\end{array}$ \\
\hline \multicolumn{4}{|c|}{ Tanggal Tanam 20 Mei 2017 } \\
\hline Luas Daun & $527,6 \mathrm{~cm}^{2}$ & $573,7 \mathrm{~cm} 2$ & $543,5 \mathrm{~cm}^{2}$ \\
\hline Ukuran Daun & Bervariasi & Bervariasi & Bervariasi \\
\hline Bulu Daun & Ada & Ada & Ada \\
\hline Bulu Tangkai & Ada & Ada & Ada \\
\hline Umur Berbunga Jantan & $40 \mathrm{hst}$ & $40 \mathrm{hst}$ & $44 \mathrm{hst}$ \\
\hline Umur Berbunga Betina & $44 \mathrm{hst}$ & $45 \mathrm{hst}$ & $45 \mathrm{hst}$ \\
\hline $\begin{array}{l}\text { Ratio bunga betina dan } \\
\text { jantan }\end{array}$ & $1: 5$ & $2: 4$ & $1: 7$ \\
\hline Ketahanan hama penyakit & Tahan & Tahan & Tahan \\
\hline
\end{tabular}

Berdasaran hasil identifikasi karakter fenotipe dan agronomi dilakukan di Kabupaten Lumajang diperoleh informasi antara lain tentang luas daun, ukuran daun, bulu daun, bulu tangkai, umur berbunga, ratio bunga betina dan jantan, dan ketahanan hama penyakit. Karakter luas daun varietas lokal Lumajang mempunyai rata-rata luas daun sekitar 527,6 $\mathrm{cm}^{2}$, lokal Malang mempunyai rata-rata luas daun sekitar $573,7 \mathrm{~cm}^{2}$, dan varietas lokal Magetan mempunyai rata-rata luas daun 543,5 $\mathrm{cm}^{2}$. Karakter ukuran daun dari semua varietas labu kuning lokal yang ditanam semuanya mempunyai ukuran daun yang bervariasi. Karakter bulu daun dan bulu tangkai dari semua labu kuning yang ditanam mempunyai sifat yang sama yaitu sama-sama mempunyai bulu pada daun dan tangkainya. Karakter umur berbunga dari ketiga varietas labu kuning yang di tanam mempunyai kriteria umur bunga jantan lebih cepat dibandingkan dengan umur bunga betina. Umur berbunga jantan dan betina pada varietas labu kuning lokal Lumajang yaitu umur 40 hst (hari setelah tanam) dan 44 hst. Varietas labu kuning lokal Malang mempunyai umur berbunga jantan dan betina yaitu 40 hst dan 45 hst. Labu kuning lokal Magetan mempunyai umur berbunga jantan dan betina yaitu 44 hst dan 45 hst. Varietas lokal malang dan lumajang mempunyai umur berbunga jantan lebih cepat dibandingkan dengan varietas lokal Magetan sedangkan umur berbunga betina varietas lokal Lumajang mempunyai umur berbunga lebih cepat dibandingkan dengan labu kuning lokal Malang dan Magetan. Ratio bunga jantan dan betina untuk semua varietas labu kuning lokal yang di tanam mempunyai jumlah bunga jantan lebih banyak dibandingkan dengan jumlah bunga betina, varitas labu kuning lokal lumajang perbandingan bunga jantan dan betina yaitu 1:5, varietas labu kuning lokal Malang perbandingannya yaitu $2: 4$, dan varietas labu kuning lokal Magetan mempunyai perbandingan 1:7 untuk jumlah bunga jantan dan bunga betina. Karakter ketahanan hama dan penyakit untuk semua varietas lokal yang di tanam mempunyai kriteria tahan (Tabel 2). 


\section{Identifikasi Karakter Agronomi}

Identifikasi karakter agronomi terdiri dari beberapa karakter antara lain umur panen, diameter buah, bobot buah, tebal daging buah, lebar rongga buah, warna daging buah, warna kulit buah, dan rambut pada tangkai buah. Umur Panen hasil penanaman yang dilakukan di kabupaten Malang dari ketiga jenis labu kuning yang diperoleh, menunjukkan umur panen labu kuning lokal Malang dan lokal Magetan mempunyai umur lebih cepat dibandingkan dengan umur panen labu kuning lokal Lumajang yaitu adalah selama 100 hari, sedangkan labu kuning lokal Lumajang mempunyai umur panen selama 103 hari. Parameter pengamatan diameter buah menunjukkan labu kuning lokal Magetan mempunyai diameter lebih besar yaitu $19 \mathrm{~cm}$, sedangkan labu kuning lokal Malang adalah $18,4 \mathrm{~cm}$ dan labu kuning lokal Lumajang mempunyai diameter lebih kecil dibandingkan yang lain yaitu $16 \mathrm{~cm}$. Tebal daging buah lokal magetan lebih besar dibandingkan dengan lokal Malang dan lokal Lumajang yaitu sebesar 3,7 cm sedangkan lokal Malang dan Lumajang yaitu sebesar $3 \mathrm{~cm}$ dan 1,9 cm.

Parameter pengamatan lebar rongga buah labu kuning lokal Magetan lebih besar dibandingkan dengan lokal Malang dan lokal Lumajang yaitu sebesar $13,5 \mathrm{~cm}$ sedangkan lokal Malang dan lokal Lumajang yaitu sebesar $12 \mathrm{~cm}$ dan $11,5 \mathrm{~cm}$. Parameter warna daging buah menunjukkan warna daging buah lokal Malang berwarna lebih orange dibandingkan dengan lokal Lumajang dan lokal Mageten yang memiliki warna daging buah orange muda atau orang agak pudar. Karakter rambut atau bulu pada tangkai menunjukkan ketiga jenis labu mempunyai rambut yang cukup tebal pada bagin tangkai buahnya. Parameter pengamatan bobot buah menunjukkan lokal magetan mempunyai bobot lebih besar dibandingkan dengan lokal Malang dan lokal Lumajang yaitu sebesar $3,2 \mathrm{~kg} /$ buah sedangkan lokal Malang dan Lumajang yaitu sebesar 2,8 $\mathrm{kg} / \mathrm{buah}$ dan 3,1 kg/buah.

Hasil identifikasi karakter agronomi yang dilakukan di kabupaten Lumajang diketahui untuk parameter umur panen labu kuning lokal Malang mempunyai umur panen lebih cepat dibandingkan dengan lokal Lumajang dan lokal Magetan yaitu selama 102 hari setelah tanam (hst). Parameter pengamatan diameter buah menunjukkan lokal Malang mempunyai diameter buah lebih besar yaitu sebesar 23,5 cm sedangkan lokal Lumajang dan lokal Magetan diameter buahnya sebesar 17 $\mathrm{cm}$ dan 20,2 cm. Tebal daging buah menunjukkan lokal Malang mempunyai tebal daging buah paling besar yaitu sebesar 3,5 cm sedangkan labu kuning lokal Lumajang mempunyai tebal daging buah yang paling kecil yaitu $2,5 \mathrm{~cm}$ dan lokal Magetan tebla daging buahnya adalah sebesar $3 \mathrm{~cm}$. Pengamatan lebar rongga buah menunjukkan lokal Lumajang memiliki rongga buah lebih besar dibandingkan dengan lokal Malang dan lokal Magetan yaitu $17 \mathrm{~cm}$ sedangkan lokal Malang dan Magetan yaitu sebesar $16,5 \mathrm{~cm}$ dan $13 \mathrm{~cm}$. Warna daging buah untuk labu kuning lokal Malang dan labu kuning lokal Magetan berwarna orange sedangkan lokal Lumajang mempunyai warna orange lebih muda atau lebih pudar. warna orange pada buah labu kuning menunjukkan kandungan betakaroten semakin tinggi. Menurut Gardjito tahun 2006, kadar betakaroten daging buah labu kuning segar adalah $19,9 \mathrm{mg} / 100 \mathrm{~g}$. Zat betakaroten ini dapat ditandai dengan warna orange yang terdapat pada tanaman, semakin tanaman tersebut menunjukkan warna orange, maka mengindikasikan bahwa kandungan 
betakaroten yang terdapat didalamnya semakin tinggi.

Parameter warna kulit buah untuk labu kuning lokal Magetan dan lokal Malang mempunyai warna seragam yaitu semua buah mempunyai warna ratarata adalah berwarna coklat sedangkan labu kuning lokal Lumajang mempunyai warna kulit buah bervariasi yaitu sebagian ada yang berwana coklat dan sebagian lagi berwarna coklat dengan corak hijau. Parameter pengamatan rambut pada tangkai buah menunjukkan ketiga jenis labu mempunyai rambut-rambut halus pada tangkainya sedangkan pada pengamatan bobot buah menunjukkan lokal Lumajang memiliki bobot lebih tinggi dibandingkan dengan lokal Malang dan lokal Magetan yaitu sebesar 3,3 $\mathrm{kg} /$ buah (Tabel 4).Labu kuning selain mencegah penyakit kanker, tanaman labu juga dapat digunakan sebagai penurun berat, mencegah bayi lahir cacat, membantu menurunkan kolesterol, sebagai sumber stamina, mencegah penuaan dini, mengobati batu ginjal, mencegah sembelit, menurunkan darah tinggi, mengobati kembung, dan mencegah penyakit jantung. Sesuai dengan teori yang menyatakan Labu kuning merupakan sumber karbohidrat yang mengandung karotenoid yang memiliki sifat fungsional sebagai antioksidan, sehingga dapat mencegah penuaan, kanker, diabetes dan katarak (Hendrasty, 2003).

Selain kandungan betakaroten labu kuning juga memiliki beberapa kandungan lain antara lain kandungan serat, vitamin dan karbohidrat yang tinggi. Selain itu, didalam waluh juga terkandung 34 kalori, lemak 0.8, $45 \mathrm{mg}$ kalsium, dan mineral 0.8 sehingga labu kuning sangat baik dikonsumsi oleh anak-anak maupun orang tua, karena kandungan gizi yang terdapat didalamnya sangat baik untuk kesehatan tubuh. Pada anak-anak dapat digunakan untuk menambah nafsu makan dan sebagai obat cacingan. Labu kuning atau waluh merupakan bahan pangan yang kaya vitamin $\mathrm{A}, \mathrm{B}$ dan $\mathrm{C}$, mineral, serta karbohidrat (Hidayah, 2010).

\section{Kesimpulan}

1. Varietas lokal mempunyai ketahanan hama dan penyakit yang relatif tahan

2. Jumlah bunga betina dari semua varietas labu kuning lokal yang ditanam mempunyai jumlah lebih sedikit dibandingkan dengan jumlah bunga jantan

3. Umur panen dari ketiga jenis labu lokal bervariasi yaitu antara $100-103$ hari setelah tanam

4. Daging buah labu kuning yang berwarna orange mengindikasikan kandungan betakaroten yang tersedia.

\section{Ucapan Terima Kasih}

a. Direktorat Riset dan Pengabdian kepada Masyarakat (DRPM) Kementerian Riset, Teknologi dan Pendidikan Tinggi yang membiayai kegiatan ini pada skema Penelitian Dosen Pemula (PDP), tahun 2017.

b. Lembaga Penelitian dan Pengabdian Masyarakat (LPPM) Universitas Tribhuwana Tunggadewi yang telah memfasilitasi kegiatan ini

\section{Daftar Pustaka}

Anonimous. 2003. Hara Mineral dan Transport Air serta Hasil Fotosintesis pada Tumbuban. http://iel.ipb.ac.id/sac/2003/sf_tumbuh an/unsur.pdf. 22 Oktober 2017.

Gardjito, M. 2006. Labu Kuning Sumber Karbohidrat Kaya Vitamin A. Tridatu Visi Komunikasi. Yogyakarta

Hendrasty, HK 2003. Tepung Labu Kuning. Yogyakarta: Kanisius.

Hidayah, R., 2010. Manfaat dan Kandungan Gizi Labu Kuning (Waluh). Hhtp://www. Borneotribune.com [ 26 Mei 2010]. 